\title{
Searching for Enforcement: Title VI Regulations and Section $1983^{*}$
}

\section{INTRODUCTION}

The life of the law has not been logic; it has been experience.

—Oliver Wendell Holmes, Jr. ${ }^{1}$

[A] page of history is worth a volume of logic.

-Oliver Wendell Holmes, Jr. ${ }^{2}$

These quotes are familiar and famous aphorisms of Supreme Court Justice Oliver Wendell Holmes, Jr. They warn against an overly formalistic approach to the law, characterized by rote recitation of blackand-white legal rules and no consideration of the real world within which such legal rules operate. These warnings have not been heeded in the legal context of Title VI of the Civil Rights Act of 1964, which protects individuals from discrimination on the basis of race by any program or entity receiving federal funding.

Imagine, now, that a hypothetical School A receives funding from the United States Department of Education. Suppose School A has a policy, governing the distribution of these federal funds, that prohibits distribution of funds to any student organization composed primarily of racial minorities - in other words, if a majority of the members of a given student organization are racial minorities, then it will not receive any funding from the school. Most people would find such a policy to be repugnant to public policy and would be unsurprised to learn that a

Matthew D. O’Neill. J.D. candidate 2013, University of Kansas School of Law; B.G.S. 2010, University of Kansas. The author would like to thank Professor Stephen R. McAllister for his helpful feedback and the University of Kansas Law Review board and staff for their assistance in editing this Comment

1. Oliver Wendell Holmes, JR., The COMmon LAW 1 (1881).

2. New York Trust Co. v. Eisner, 256 U.S. 345, 349 (1921). 
private individual could bring suit under Title VI to enforce its protection against the discrimination. ${ }^{3}$

Imagine, however, that School A tweaks its policy slightly. Instead of expressly basing its policy on race, suppose that it bases the policy on the size of the student organization. For example, the policy may prohibit the distribution of funds to any student organization that has a total membership of less than one percent of the school's total population. This policy may seem innocuous on its face. The policy may, however, have the same effect as the policy expressly based on race-that is, no funding for student organizations composed primarily of racial minorities. School A may be racially homogenous, and student organizations composed primarily of minorities may not have a total membership equal to or greater than one percent of School A's total population. Perhaps School A tweaked its policy in this way to achieve the same result without expressly basing its policy on race, thereby avoiding suit under Title VI. Surely such a policy is no less repugnant to public policy than one expressly based on race, particularly when the underlying motive for each policy is the same.

As it turns out, private individuals may bring suit under Title VI only to challenge policies that expressly (intentionally) discriminate on the basis of race. $^{4}$ Title VI does not reach a policy that has a disproportionally adverse (disparate) impact on particular racial groups, so long as the policy does not intentionally discriminate on the basis of race-such as the second hypothetical policy outlined above. Title VI does, however, direct federal agencies distributing federal funds-such as the Department of Education-to pass regulations effectuating the goal, or purpose, of Title VI. ${ }^{5}$

Suppose that the Department of Education, pursuant to this directive, has passed a regulation prohibiting policies that have a disparate impact on particular racial groups. Such regulations are common, ${ }^{6}$ but the United States Supreme Court has held that private individuals cannot bring suit under Title VI to enforce them. ${ }^{7}$ This appears to allow School A to achieve its discriminatory objective by merely masking its discriminatory intent. This approach to Title VI fails to consider the

3. See infra Part II.B.1.

4. See Alexander v. Sandoval, 532 U.S. 275, 279-80 (2001) (noting that private individuals may bring suit to enforce Title VI and that Title VI reaches only intentional discrimination).

5. See infra Part II.A.1.

6. E.g., 28 C.F.R. $\S 42.104$ (2011) (Department of Justice regulation); 49 C.F.R. § 21.5 (2011) (Department of Transportation regulation).

7. Sandoval, 532 U.S. at 293. 
real-world context in which legal rules operate, which is precisely the evil that Justice Holmes warned against. This Comment advocates an alternative mechanism for enforcing regulations that prohibit policies having a disparate impact on certain racial groups: the $\S 1983$ action. $^{8}$ Use of $\S 1983$ to enforce disparate impact regulations would replace an overly formalistic approach to Title VI with a functional approach that better meets the overall goals and purpose of Title VI and fits within existing precedent. Furthermore, adoption of this functionalist approach is warranted, because the current, overly formalistic approach is based on an untenable distinction between intentional and disparate impact discrimination.

Part II provides an overview of the areas of law pertinent to this Comment-Title VI and $\S 1983 .{ }^{9}$ Part II.A outlines the relevant statutory provisions. Part II.B examines case law that is relevant to the statutory provisions outlined in Part II.A. Part II.C discusses the circuit split that has developed over the application of $\S 1983$ to enforce federal regulations promulgated under Title VI.

Part III analyzes the justification for using $\S 1983$ to enforce regulations prohibiting disparate impact discrimination. Part III.A examines the functionalist virtues of allowing $\S 1983$ actions to enforce disparate impact regulations. Part III.B notes that allowing such use of $\S$ 1983 fits within existing precedent. Part III.C demonstrates that such a use of $\S 1983$ is both justified and needed because the current state of Title VI law is based on an untenable distinction between intentional and disparate impact discrimination. Finally, Part IV concludes by briefly summarizing these arguments and advocating, once more, for the use of $\S 1983$ to enforce regulations prohibiting disparate impact discrimination.

8. This alternative suggestion is not new. See Bradford C. Mank, Using § 1983 to Enforce Title VI’s Section 602 Regulations, 49 U. Kan. L. REV. 321 (2001). Professor Mank provides a more in-depth analysis than this Comment of all elements required in a § 1983 action. Professor Mank makes the argument, as does this Comment, that $\S 602$ disparate impact regulations create enforceable rights that are required for a $§ 1983$ action. Id. at 365-67. Professor Mank’s article, however, was written before two key Supreme Court decisions relevant to the analysis here. See Gonzaga v. Doe, 536 U.S. 273 (2002); Alexander v. Sandoval, 532 U.S. 275 (2001). In fact, Professor Mank's analysis relies on the district court case that the Supreme Court overturned in Sandoval. Mank, supra, at 366-67. This Comment, then, in some sense, revisits many of the arguments made in Professor Mank's article and assesses their viability given key developments in Supreme Court precedent and Title VI and § 1983 law.

9. 42 U.S.C. § 1983 (2006). 


\section{BACKGROUND}

Although both areas of law relevant to this Comment-Title VI and $\S 1983$ — are based on statutory provisions, they are not the sole authority in either area. Cases applying each statute have developed the body of law in both the Title VI and § 1983 context.

\section{A. The Relevant Statutory Provisions}

1. Title VI: The Statutory Basis for the Individual Right to Be Free from all Types of Racial Discrimination

Section 601 of Title VI provides that "No person in the United States shall, on the ground of race, color, or national origin, be excluded from participation in, be denied the benefits of, or be subjected to discrimination under any program or activity receiving Federal financial assistance." ${ }^{\text {Section }} 602$ of Title VI provides, in part:

Each Federal department and agency which is empowered to extend Federal financial assistance to any program or activity, by way of grant, loan, or contract other than a contract of insurance or guaranty, is authorized and directed to effectuate the provisions of section [601] . . . with respect to such program or activity by issuing rules, regulations, or orders of general applicability which shall be consistent with achievement of the objectives of the statute authorizing the financial assistance in connection with which the action is taken. ${ }^{1}$

Section 602's reference to $\S 601$-directing federal agencies to promulgate regulations effectuating the provisions of § 601-makes clear that the two provisions do not operate wholly independently of one another. As $\S 602$ regulations are to be promulgated to effectuate the provisions of $\S 601$, they may, in some sense, elucidate the content of $\S$ 601 . Section 602 regulations therefore cannot be understood without reference to $\S 601$ and how the regulations are intended to effectuate those provisions. Simply put, § 601 may be understood as the end goal and $\S 602$ regulations as the means by which to accomplish it.

Pursuant to $\S 602$, several federal departments and agencies have issued rules, regulations, or orders of general applicability prohibiting funding recipients from utilizing "criteria or methods of administration which have the effect of subjecting individuals to discrimination because

10. Id. § 2000d.

11. Id. § 2000d-1. 
of their race, color, or national origin.”12 These regulations prohibit disparate impact discrimination by entities receiving federal funding from a federal department or agency having such a regulation.

The Supreme Court has held that an implied private cause of action may be used to enforce $\S 601$, but not $\S 602$ disparate impact regulations. ${ }^{13}$ Although there is no private cause of action to enforce the regulations passed pursuant to $\S 602$, there may be other mechanisms by which private individuals can seek enforcement of those regulations. ${ }^{14}$ One potential alternative is the use of $\S 1983$ to enforce regulations passed pursuant to $\S 602 .^{15}$

\section{42 U.S.C. $\S 1983$ : The Mechanism for Enforcing Individual Federal} Rights

Section 1983 provides, in pertinent part:

Every person who, under color of any statute, ordinance, regulation, custom, or usage, of any State ... subjects, or causes to be subjected, any citizen of the United States or other person within the jurisdiction thereof to the deprivation of any rights, privileges, or immunities secured by the Constitution and laws, shall be liable to the party injured in an action at law, suit in equity, or other proceeding for redress . . . ${ }^{16}$

Section 1983 therefore, by its own terms, provides a private cause of action for individuals to enforce the "rights, privileges, or immunities secured by the Constitution and [federal] laws." " As is clear from the quoted portion of the statute, a $\S 1983$ claim requires more than a violation of a federal right, ${ }^{18}$ but this Comment will focus on only that element of a claim.

Section 1983 does not create any federal substantive rights; rather, it was intended to provide a remedy for the violation of rights secured by the Constitution or a federal statute. ${ }^{19}$ Rights secured by federal statute,

12. 28 C.F.R. § 42.104 (2011) (Department of Justice regulation); see also 49 C.F.R. § 21.5 (2011) (Department of Transportation regulation).

13. See infra Part II.B.

14. See infra Part II.B.

15. See infra Part II.B.

16. 42 U.S.C. § 1983 (2006).

17. Id.

18. See Martin A. Schwartz, Fundamentals of Section 1983 Litigation, in 25TH ANNUAL Section 1983 Civil Rights Litigation 5-14 (George C. Pratt \& Martin A. Schwartz, co-chairs, Practising Law Institute 2008) (providing an overview of the elements of a § 1983 claim).

19. Id. at 16. 
enforceable by a $\S 1983$ action, may include those rights secured by Title VI. ${ }^{20}$

\section{B. The Relevant Case Law}

1. Title VI Case Law

Part II.B.1 examines the case law that has led to the development of the present state of Title VI law. This case law makes clear that Title VI contains an implied private cause of action to enforce $\S 601 .^{21}$ This case law makes equally clear, however, that Title VI does not contain an implied private cause of action to enforce regulations promulgated pursuant to $\S 602 .^{22}$ It is therefore unclear how, or if, private individuals may enforce $\S 602$ disparate impact regulations.

a. Cannon v. University of Chicago and the Genesis of Title VI's Implied Private Cause of Action

In Cannon v. University of Chicago, ${ }^{23}$ the Supreme Court held that Title IX of the Education Amendments of $1972^{24}$ could be enforced by an implied private cause of action. ${ }^{25}$ Although Cannon dealt with Title IX, the Court's reasoning makes clear that its holding applies with equal force to Title VI. ${ }^{26}$ The Court noted that Title IX had been patterned after Title VI and that the drafters of Title IX explicitly assumed that Title IX would be interpreted in the same manner as Title VI. ${ }^{27}$

By the time Title IX was enacted, Title VI repeatedly had been interpreted to include an implied private cause of action, albeit by lower federal courts. ${ }^{28}$ Congress was-and is—assumed to know the law and legislate against that background. ${ }^{29}$ Coupling this assumption with the fact that Congress had explicitly and repeatedly referenced Title VI while

\footnotetext{
20. See Sam Spital, Note, Restoring Brown's Promise of Equality After Alexander v. Sandoval: Why We Can't Wait, 19 HARV. BLACKLETTER L.J. 93, 96 (2003) (stating a fair reading of the Supreme Court's precedents allow a § 1983 action to enforce Title VI regulations).

21. See infra Part II.B.1.a.

22. See infra Part II.B.1.b.

23. 441 U.S. 677 (1979).

24. 20 U.S.C. §§ 1681-1688 (2006).

25. Cannon, 441 U.S. at 717.

26. Id. at 694-96.

27. Id. at 696 .

28. Id.

29. Id. at 696-98.
} 
drafting Title IX, the Court felt "especially justified" in holding that Title IX contained an implied private cause of action. ${ }^{30}$ Implicit in, and a necessary condition to, this holding was the Court's understanding that Title VI contains an implied cause of action. ${ }^{31}$ Cannon thus may stand for the proposition that Title VI contains an implied private cause of action.

Beyond Cannon's focus on legislative history, it also considered the statutory language of Title IX - and, by extension, Title VI-to be crucial to its holding that the statute contained an implied private cause of action. ${ }^{32}$ For a statute to contain a private cause of action, the statute must first confer a personal right, which the private cause of action is intended to enforce. ${ }^{33}$ Both Title VI and Title IX confer a personal right. ${ }^{34}$ Crucial to this determination was the fact that the language of both statutes focuses on the class for whose benefit they were enacted. ${ }^{35}$ The language of Title VI and Title IX focuses on the benefitted class and its protection-"No person... shall... be subjected to discrimination" - and is different from a hypothetical statute that simply prohibits the recipients of federal funds from discriminating on the basis of race or sex. ${ }^{36}$ The language of such a hypothetical statute would not create a personal right and would counsel against finding an implied private cause of action for its enforcement. ${ }^{37}$ Statutory language conferring a personal right upon members of a benefitted classpotentially enforceable by a private cause of action-almost certainly has to be phrased in terms that focus on the benefitted class. ${ }^{38}$ Because both Title VI and Title IX are phrased in such language, the Court found that they conferred a personal right upon members of the benefitted class and went on to imply a private cause of action to enforce that conferred right. $^{39}$

30. Id. at 697.

31. The Court, in effect, holds that Title IX contains an implied private cause of action because its drafters explicitly and repeatedly referenced Title VI. Such references to Title VI would be meaningless, as to the question of whether Title IX contained an implied private cause of action, if Title VI was not understood to contain an implied private cause of action. Id. at 694-98.

32. Id. at 689-94.

33. Id. at 690 n.13.

34. 20 U.S.C. § 1681 (2006); 42 U.S.C. § 2000d.

35. See Cannon, 441 U.S. at 690.

36. Id.; see also id. at 690-93.

37. See id. at 691 ("There would be far less reason to infer a private remedy in favor of individual persons if Congress, instead of drafting Title IX with an unmistakable focus on the benefited class ....”).

38. Id. at 690 n.13.

39. Id. at 709 . 
Both the Supreme Court and Congress have affirmed the holding from Cannon that Title VI contains an implied private cause of action. ${ }^{40}$ The Supreme Court, after Cannon, has explicitly recognized an implied private cause of action to enforce Title VI. ${ }^{41}$ Furthermore, Congress effectively recognized a private cause of action to enforce Title VI when it abrogated state sovereign immunity, in $\S 1003$ of the Rehabilitation Act Amendments of $1986,{ }^{42}$ for violations of Title VI. ${ }^{43}$ It is therefore clear that Title VI is enforceable through an implied private cause of action. The scope of this implied private cause of action, however, is limited. ${ }^{44}$

b. Alexander v. Sandoval and the Limitation of Title VI's Implied

Private Cause of Action to Cases of Intentional Discrimination

In Alexander v. Sandoval, the Supreme Court limited the scope of the implied private cause of action to enforce Title VI. ${ }^{45}$ In Sandoval, the issue before the Court was whether an implied private cause of action existed to enforce disparate impact regulations promulgated pursuant to $\S$ 602 of Title VI. ${ }^{46}$ The Court ultimately concluded that it did not. ${ }^{47}$ Because Sandoval's analysis of Title VI is highly relevant to the question of whether $\S 1983$ may be used to enforce $\S 602$ disparate impact regulations, a close examination of the Sandoval opinion is warranted.

The facts of Sandoval are straightforward. In 1990, during the "English-only" movement, Alabama amended its constitution to make English the official language of Alabama. ${ }^{48}$ Pursuant to this amendment, the Alabama Department of Public Safety decided to administer state driver's license examinations only in English. ${ }^{49}$ The Alabama Department of Public Safety had accepted funding from the United States Departments of Justice and Transportation, thereby subjecting

\footnotetext{
40. See infra Part II.B.1.b.

41. See infra Part II.B.1.b.

42. 42 U.S.C. § 2000d-7 (2006).

43. See Franklin v. Gwinnett Cnty. Pub. Sch., 503 U.S. 60, 72 (1992) (stating that 42 U.S.C. §

2000d-7 "cannot be read except as a validation of Cannon's holding.").

44. See infra Part II.B.1.b.

45. 532 U.S. 275, 293 (2001) (holding that the implied private cause of action may not be used to enforce disparate impact regulations promulgated pursuant to § 602).

46. Id. at 279.

47. Id. at 293.

48. Id. at 278-79.

49. Id. at 279 .
} 
itself to the provisions of Title VI. ${ }^{50}$ Both the Departments of Justice and Transportation had promulgated regulations, pursuant to $\S 602$, prohibiting funding recipients from administering the funds in a manner that had the effect of discriminating on the basis of race, color, or national origin. ${ }^{51}$ These regulations prohibited disparate impact, in addition to intentional, discrimination. ${ }^{52}$ Sandoval brought suit seeking to enjoin the English-only policy. ${ }^{53}$ Sandoval argued that the Englishonly policy had the effect of discriminating against non-English speakers on the basis of national origin, in violation of the disparate impact regulations promulgated pursuant to $\S 602 .{ }^{54}$ Both the district court and the Eleventh Circuit ruled in favor of Sandoval, and an appeal to the Supreme Court followed. ${ }^{55}$

As an initial matter, the Supreme Court took as given three aspects of Title VI. ${ }^{56}$ First, the Court found it well settled that an implied private cause of action is available to enforce $\S 601$ of Title VI. ${ }^{57}$ Second, the Court's precedents made clear that $\S 601$ prohibits only intentional discrimination—not disparate impact discrimination. ${ }^{58}$ Third, the Court assumed that $\S 602$ regulations-like those at issue in Sandoval-could validly prohibit disparate impact discrimination, even though § 601 permits it and prohibits only intentional discrimination. ${ }^{59}$ The issue, then, was whether an implied private cause of action was available to enforce the valid disparate impact regulations promulgated pursuant to $\S$ $602 .^{60}$

The Court began its analysis by rejecting the claim that the Court's precedents required it to find that an implied private cause of action existed to enforce $\S 602$ disparate impact regulations. ${ }^{61}$ The Court

\footnotetext{
50. Id. at 278 .

51. Id. (citing 28 C.F.R. § 42.104(b)(2) (2011) (Department of Justice regulation); 49 C.F.R. § 21.5(b)(2) (Department of Transportation regulation)).

52. See id. at 281 (stating the regulations prohibited activities having a disparate impact on racial groups and are assumed to be valid under § 602).

53. Id. at 279 .

54. Id.

55. Id.

56. Id.

57. Id. at $279-80$.

58. Id. at $280-81$.

59. Id. at 281-82. This Comment does not address whether § 602 disparate impact regulations are valid, but other commentators have discussed the issue. See, e.g., Bradford C. Mank, Are Title VI's Disparate Impact Regulations Valid?, 71 U. CIN. L. REV. 517 (2002) (arguing that such regulations are valid).

60. Sandoval, 532 U.S. at 279.

61. Id. at 282
} 
interpreted its precedents to hold only that an implied private cause of action is available to enforce Title VI's ban on intentional discrimination. ${ }^{62}$ The Court's precedents were silent on-or had never reached-the issue of whether the implied private cause of action extended to $\S 602$ regulations prohibiting disparate impact discrimination. ${ }^{63}$ Thus, precedent did not require the Court to find that the implied private cause of action extended to those regulations.

The Court then considered whether Congress intended for a private cause of action to enforce $\S 602$ regulations prohibiting disparate impact discrimination. $^{64}$ The Court, given its assumptions about Title VI, ${ }^{65}$ ultimately concluded that Congress had not so intended. ${ }^{66}$ The private cause of action to enforce $\S 601$ 's prohibition on intentional discrimination, according to the Court, undoubtedly extended to $\S 602$ regulations also prohibiting intentional discrimination. ${ }^{67}$ Because $\S 601$ prohibits intentional discrimination, § 602 regulations prohibiting the same were deemed an authoritative construction of $\S 601 .^{68}$ "A Congress that intends [ $\S 601]$ to be enforced through a private cause of action," the Court reasoned, "intends the authoritative interpretation of [ $\S 601]$ to be so enforced as well.",69

Section 601, however, prohibits only intentional discrimination. ${ }^{70}$ The Court therefore found that $\S 602$ regulations prohibiting disparate impact discrimination are not authoritative constructions of, and do not apply to, $\S 601 .^{71}$ Rather, they prohibit a type of discrimination that $\S 601$ permits. $^{72}$ Because of this, the Court found it "clear that the private right of action to enforce $\S 601$ does not include a private right to enforce” $\S 602$ regulations prohibiting disparate impact discrimination. ${ }^{73}$ A private cause of action to enforce $\S 602$ regulations prohibiting disparate impact discrimination - a type of discrimination permitted by $\S 601$ - "must come, if at all, from the independent force of $\S 602 ., " 74$

\footnotetext{
62. Id. at 282-84.

63. Id. at 281-84.

64. Id. at 284.

65. See supra notes 566-590 and accompanying text.

66. Sandoval, 532 U.S. at 284.

67. Id.

68. Id.

69. Id.

70. Id. at 280 .

71. Id. at 285.

72. Id.

73. Id.

74. Id. at 286.
} 
The Court held that congressional intent is the dispositive factor in determining whether $\S 602$ contains an implied private cause of action to enforce disparate impact regulations promulgated thereunder. ${ }^{75}$ If Congress did not intend to provide such a remedy, the Court cannot imply or create it, even if such a remedy is desirable as a matter of public policy or appears compatible with Title VI as a whole. ${ }^{76}$ This reasoning exemplifies the Court's overly formalistic approach to Title VI. Only an overly formalistic approach would prohibit private enforcement by adhering to a legal rule that mandates a finding of congressional intent to create such a remedy, even though private enforcement is perfectly compatible with Title VI-in fact, private enforcement would further the overall goals and purpose of Title VI, as § 602 regulations are promulgated to effectuate the antidiscrimination provision of $\S 601$.

Under this overly formalistic approach, the Sandoval Court found that the text and structure of Title VI evinces no congressional intent to provide a private cause of action to enforce the disparate impact regulations promulgated under $\S 602 .^{77}$ The language focusing on Title VI's protected class, which was crucial to Cannon's holding that $\S 601$ confers federal rights and contains a private cause of action to enforce those rights, ${ }^{78}$ is absent from $\S 602 .^{79}$ Instead, the language of $\S 602$ focuses on the federal agencies that distribute federal funds and regulate the recipients, which, according to the Court, evinces no intent to confer rights, much less a private cause of action to enforce them. ${ }^{80}$ Furthermore, the Court interpreted $\S 602$ to limit federal agencies to "effectuat[ing] rights already created by $\S 601 . " 81$ Congress therefore could not have intended a private cause of action to enforce rights created independent of $\S 601$, such as those rights created by $\S 602$ disparate impact regulations. ${ }^{82}$

In addition to the text of $\S 602$, the Court found that its structure counseled against finding an implied private cause of action. ${ }^{83}$ Section

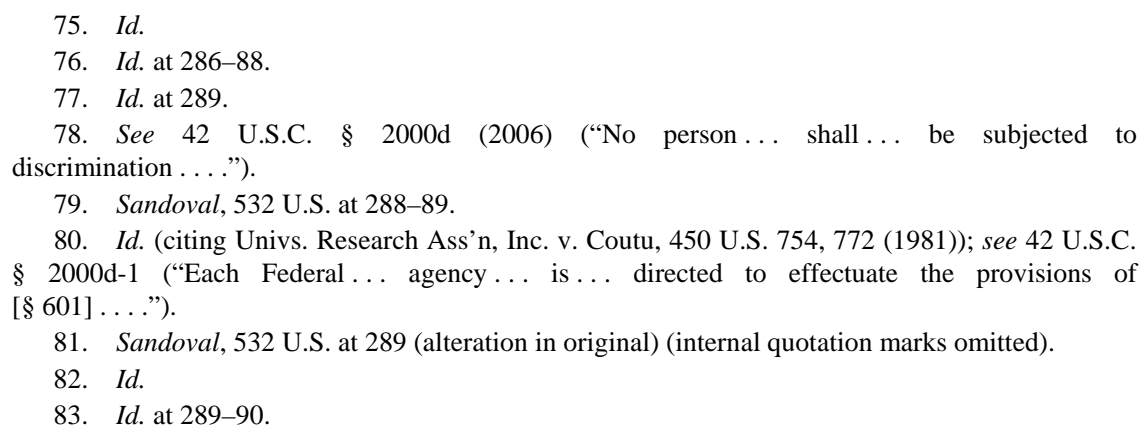


602 explicitly provides methods by which to enforce regulations promulgated thereunder. ${ }^{84}$ These explicit methods of enforcement are subject to "elaborate" restrictions, which, to the Court, suggested that Congress did not intend to provide a private cause of action to enforce $\S 602$ regulations. ${ }^{85}$

In response to the argument that $\S 602$ regulations create rights and therefore must be enforceable by a private cause of action, the Court held that although a regulation may invoke a statutorily created private cause of action for its enforcement, a regulation may not create a private cause of action that Congress did not authorize. ${ }^{86}$ Finally, the Court rejected the argument that Congress had "ratified" previous decisions finding a private cause of action to enforce $\S 602$ disparate impact regulations. ${ }^{87}$ This argument failed because, as the Court had explained, its previous decisions had not, in fact, found, or even assumed, a private cause of action existed to enforce $\S 602$ disparate impact regulations. ${ }^{88}$

Justice Stevens, joined by three other Justices, dissented from the decision in Sandoval. ${ }^{89}$ The dissent disagreed with nearly every step of the majority's analysis. First, the dissent argued that the Court's precedents supported a finding that $\S 602$ disparate impact regulations are enforceable by a private cause of action. ${ }^{90}$ Next, the dissent argued that the text and structure of Title VI supported finding a private cause of action to enforce $\S 602$ disparate impact regulations ${ }^{91}$ and that Congress intended to provide a private cause of action to enforce such regulations. ${ }^{92}$ Finally, the dissent argued that all $\S 602$ regulations-not just those prohibiting intentional discrimination-define the scope of rights enforceable by a private cause of action. ${ }^{93}$

Interestingly, the dissent suggested that $\S 602$ disparate impact regulations may still be enforced by a $\S 1983$ action. ${ }^{94}$ In his dissent, Justice Stevens stated that "litigants who in the future wish to enforce the Title VI regulations against state actors in all likelihood must only

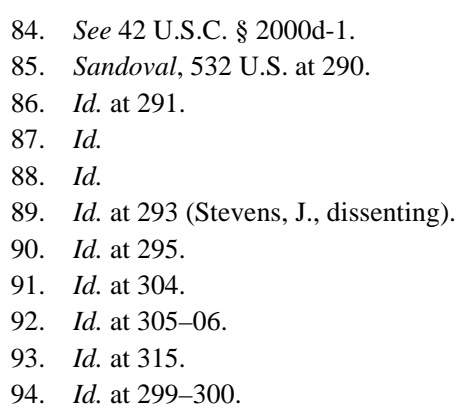


reference $\S 1983$ to obtain relief . ...95 The majority addressed only the issue of whether $\S 602$ contains an implied private cause of action to enforce disparate impact regulations promulgated thereunder; ${ }^{96}$ the majority said nothing about whether $\S 1983$ may be used to enforce $\S 602$ disparate impact regulations. ${ }^{97}$ It would thus appear that $\S 1983$ provides a potential alternative for enforcing $\S 602$ disparate impact regulations. ${ }^{98}$

\section{Section 1983 Case Law}

Although § 1983 may provide an alternative enforcement mechanism for $\S 602$ disparate impact regulations, it remains to be seen whether $\S 1983$ is, in fact, an appropriate mechanism for doing so. Section 1983 case law makes clear that although $\S 1983$ protects against both statutory and constitutional violations, ${ }^{99}$ it provides a remedy for violations of a federal right, not merely violations of a federal statute. ${ }^{100}$ The key question, then, in determining if $\S 1983$ may be used to enforce $\S 602$ disparate impact regulations, is whether those regulations create, or define, federal rights. Although various factors may help determine whether a federal statute creates a federal right, ${ }^{101}$ a federal statute does so only if it unambiguously evinces congressional intent to do so. ${ }^{102}$

If a federal statute is found to create a federal right, there is a strong presumption that $\S 1983$ may be used to enforce that right. ${ }^{103}$ Although not addressed in this Comment, the presumption may be overcome by showing that Congress intended to foreclose $\S 1983$ as a means of enforcement by either (1) explicitly so providing or (2) by providing a comprehensive remedial scheme that would be inconsistent with the use of $\S 1983$ as a means of enforcement. ${ }^{104}$ As others have noted, Title VI

95. Id. at 300 .

96. Id. at 293 (majority opinion).

97. See Spital, supra note 20, at 118 (“[N]o court has held that Sandoval resolves the question of whether $\S 602$ [] regulations are enforceable under $\S 1983 . ”)$.

98. Id. ("[T]he inquiry into Congressional intent in determining whether a statute confers a private cause of action is clearly distinct from the inquiry as to whether, combined with its regulations, it creates enforceable rights under § 1983.” (quoting Mank, supra note 8, at 323)).

99. See infra Part II.B.2.a.

100. See infra Part II.B.2.b.

101. See infra Part II.B.2.c.

102. See infra Part II.B.2.d.

103. See Mank, supra note 8, at 334 ("[T]he Supreme Court has emphasized that once a court finds an enforceable right under the three-part test, there is a strong presumption against preclusion and in favor of enforcing those federal rights under § 1983.”).

104. Id. at 336. 
does not explicitly foreclose use of $\S 1983$, and it is unlikely that Title VI's remedial scheme is so comprehensive as to foreclose the use of $\S 1983$ as an enforcement mechanism if the statute creates rights. ${ }^{105}$

a. Maine v. Thiboutot and the Most Expansive, Plain Language

Interpretation of $\S 1983$ 's Reach as to Statutory Rights

The issue before the Supreme Court in Maine v. Thiboutot was "whether § 1983 encompasses claims based on purely statutory violations of federal law." ${ }^{106}$ In Thiboutot, the Thiboutots brought suit under $\S 1983$, alleging that the State of Maine had deprived them of benefits due under the federal Social Security Act. ${ }^{107}$

The Thiboutot Court held that $\S 1983$ claims could be maintained based solely on violations of federal statutes. ${ }^{108}$ To reach this conclusion, the Court relied upon the plain language of $\S 1983 .{ }^{109}$ Because $\S 1983$ does not plainly limit which laws may support a claim, the Court held that a $\S 1983$ claim could be maintained based solely on a violation of any federal statute. ${ }^{110}$ In addition to the plain language of $\S 1983$, the Court noted that its precedents suggested that $\S 1983$ claims could be maintained based on "violations of federal statutory as well as constitutional law."

b. Pennhurst State School \& Hospital v. Halderman and the Limitation of $\S 1983$ to Violations of Federal Rights

In Pennhurst State School \& Hospital v. Halderman, ${ }^{112}$ the Court found that the statutory provision at issue-passed pursuant to Congress's spending power ${ }^{113}$ — did not confer any substantive rights. ${ }^{114}$ Because the statutory provision did not confer any substantive rights, the Court did not reach the question of whether $\S 1983$ could be used to

\footnotetext{
105. See id. at 367-68 (explaining that Title VI’s remedial scheme does not preclude § 1983 suits).

106. 448 U.S. 1,3 (1980).

107. Id.

108. Id. at 4 .

109. Id.

110. Id. at 5 .

111. Id. at 4 .

112. 451 U.S. 1 (1981).

113. Id. at 15.

114. Id. at 11
} 
enforce those rights. ${ }^{115}$ The Court thus implied that $\S 1983$ provides a remedy only for violations of federal rights, not merely violations of federal statutes.

The Court further noted that the usual remedy for state noncompliance with federally imposed conditions under spending power legislation is an action by the federal government to terminate the funds - not a private cause of action, such as one under $\S 1983 .{ }^{116}$ Although Thiboutot suggested that a $\S 1983$ action could be maintained based on violation of a federal statute, the Pennhurst Court distinguished Thiboutot on the ground that Thiboutot involved the violation of a federal right, not just a statute. ${ }^{117}$ Because the Court did not decide that the statutory provision at issue in Pennhurst conferred any substantive federal rights, § 1983 was not available as an enforcement mechanism. ${ }^{118}$ Pennhurst thus makes clear that use of $\S 1983$ is limited to situations involving violations of federal rights. The question then becomes whether a federal statute creates, or gives rise to, a federal right.

c. Blessing v. Freestone and the Factors That Help Determine Whether a Federal Statute Creates a Federal Right

In Blessing v. Freestone, the Supreme Court reiterated that a $§ 1983$ action may be maintained only for violation of a federal right, not merely violation of a federal statute. ${ }^{119}$ The Blessing Court then recognized three factors that the Court must consider in determining whether a statute or statutory provision gives rise to a federal right. ${ }^{120}$

The first of these factors is whether Congress intended the statutory provision at issue to benefit the plaintiff. ${ }^{121}$ Second, the plaintiff must demonstrate that the right protected by the statutory provision is sufficiently well-defined to be judicially enforceable. ${ }^{122}$ Lastly, the statutory provision giving rise to the federal right must clearly impose a binding obligation on the states - that is, the statutory provision must be phrased as mandatory. ${ }^{123}$

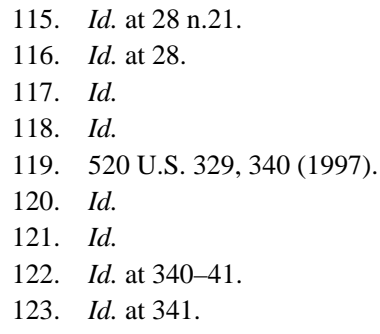


A finding that a statutory provision gives rise to a federal right does not guarantee that the right is enforceable by a $\S 1983$ action. ${ }^{124}$ Such a finding does, however, create a rebuttable presumption that the federal right is enforceable by a $\S 1983$ action. ${ }^{125}$ This presumption may be overcome if Congress has (1) expressly prohibited a $\S 1983$ action in the statutory provision itself or (2) impliedly done so "by creating a comprehensive enforcement scheme that is incompatible with individual enforcement under § 1983.”126

d. Gonzaga University v. Doe and the More Stringent Standard for Determining Whether a Federal Statute Creates a Federal Right

In Gonzaga University v. Doe, the Supreme Court provided further guidance for determining whether a statutory provision gives rise to federal rights enforceable by $\S 1983 .{ }^{127}$ The Gonzaga Court also established the relationship between implied private causes of action and $\S 1983$ actions. ${ }^{128}$ The Court first dealt with the issue of determining whether a statutory provision confers a federal right. The Court rejected the argument that a statutory provision gives rise to a federal right so long as Congress intended for the statutory provision to "benefit" putative plaintiffs. ${ }^{129}$ Instead, a statutory provision confers a federal right, enforceable under $\S 1983$, only if Congress "unambiguously" intends to do so. ${ }^{130}$ The focus must be on congressional intent to confer a right, which is something more than a benefit or interest. ${ }^{131}$

In reaching this conclusion, the Gonzaga Court recognized that the three Blessing factors for determining whether a statutory provision confers a federal right, enforceable by a $\S 1983$ action, had created much confusion. ${ }^{132}$ The Blessing factors had been interpreted to allow a $\S 1983$ claim "so long as the plaintiff falls within the general zone of interest that the statute is intended to protect."133 Such an interpretation, according to the Gonzaga Court, was incompatible with Blessing's

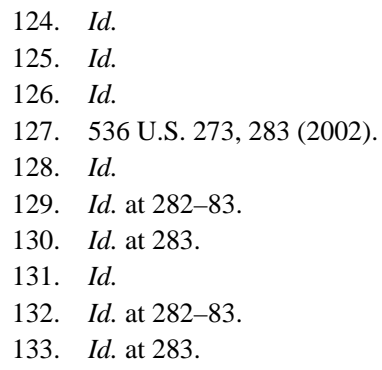


emphasis on the violation of rights as the basis for a $\S 1983$ action, because interests and benefits do not rise to the level of being substantive rights. ${ }^{134}$ Thus, the three Blessing factors now appear relevant only to the extent that they "unambiguously" evince congressional intent to confer a federal right. ${ }^{135}$ This standard-requiring an unambiguously conferred right to support a $\S 1983$ claim-creates a direct relationship between implied private causes of action and § 1983 claims. ${ }^{136}$

The Gonzaga Court recognized that the inquiry of whether a statutory provision confers a right enforceable by a $\S 1983$ action overlaps with the question of whether a particular statute contains an implied private cause of action. ${ }^{137}$ Determining whether a particular statute contains an implied private cause of action is a two-step inquiry. ${ }^{138}$ First, Congress must have "intended to create a federal right." 139 Second, assuming Congress intended to create a federal right, it must also have intended to create a private remedy in order for the Court to imply a private cause of action. ${ }^{140}$

A § 1983 plaintiff need not demonstrate congressional intent to provide a private remedy. ${ }^{141}$ Section 1983 is itself a congressionally provided mechanism for enforcing rights secured by the Constitution and federal statutes. ${ }^{142}$ It is this feature of $\S 1983$ that makes it an attractive alternative mechanism to enforce $\S 602$ disparate impact regulations: it eliminates a formalistic rule requiring congressional intent to create a private remedy because $\S 1983$ is itself the private remedy.

To support a $\S 1983$ action for violation of a right secured by federal statute, a plaintiff must initially demonstrate that Congress intended the statutory provision at issue to confer a right. ${ }^{143}$ This initial inquiry is identical to the initial inquiry in determining whether a particular statute contains an implied private cause of action-did Congress intend the statutory provision at issue to confer, or create, any right at all? ${ }^{144}$ The Court's precedents for determining whether Congress intended to create

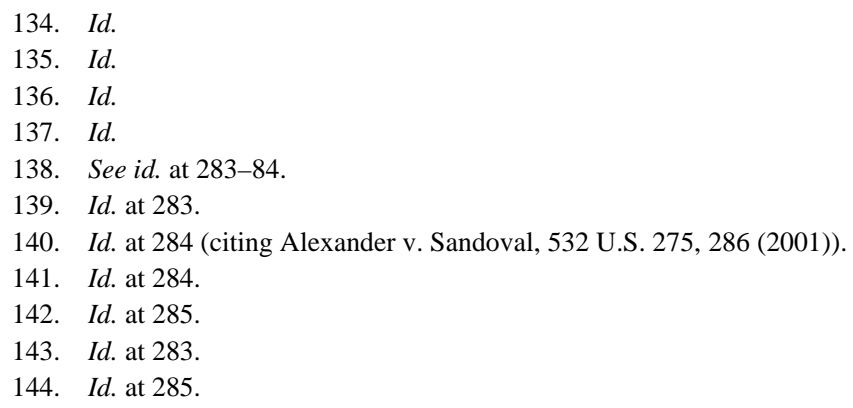


a right for the purpose of implying a private cause of action therefore control in cases determining whether Congress intended to create a right enforceable under $§ 1983$, and vice versa. ${ }^{145}$

In advocating for the use of $\S 1983$ to enforce $\S 602$ disparate impact regulations, commentators have argued that plaintiffs bear a lighter burden in demonstrating the availability of $\S 1983$ than in demonstrating that a statute contains an implied private cause of action. ${ }^{146}$ This argument relies on the premise that $\S 1983$ plaintiffs need only satisfy the Blessing factors to demonstrate that a federal statute creates a right enforceable by $\S 1983 .{ }^{147}$ Gonzaga casts doubt upon-or, perhaps, rejects - this premise, as it requires a showing of congressional intent to create a right. ${ }^{148}$ Proving congressional intent to create a right is more burdensome than satisfying the Blessing factors, but it is identical to the initial inquiry in determining whether a federal statute contains an implied private cause of action. Although $\S 1983$ plaintiffs need not prove congressional intent to create a private remedy, they, like plaintiffs advocating for an implied private cause of action, must prove congressional intent to create a right in the first instance.

In Gonzaga, the Court ultimately held that the statutory provisions at issue-the Family Educational Rights and Privacy Act's (FERPA's) nondisclosure provisions ${ }^{149}$ - do not evince a congressional intent to create, or confer, rights and therefore are not enforceable by a $\S 1983$ action. ${ }^{150}$ First, the Court noted that FERPA's nondisclosure provisions do not contain any "rights-creating" language that is crucial to finding that Congress intended to create a right, whether it be enforceable by an implied private cause of action or $\S 1983 .{ }^{151}$ The language of FERPA's nondisclosure provisions focuses not on the benefitted class, but on the Secretary of Education and how she is to distribute the funds. ${ }^{152}$ The nondisclosure provisions therefore do not confer any right enforceable by $\S 1983 .{ }^{153}$

\footnotetext{
145. Id.

146. See Mank, supra note 8, at 353-58 (discussing the importance of congressional intent to create a private remedy and $\S 1983$ 's explicit authorization of a private cause of action).

147. See id. at 358; see id. at 332-34.

148. Gonzaga, 536 U.S. at 283.

149. 20 U.S.C. § $1232 \mathrm{~g}(2006)$.

150. Gonzaga, 536 U.S. at 290.

151. Id. at 287.

152. Id.

153. Id.
} 
The Court's conclusion that FERPA's nondisclosure provisions confer no individual right was further supported by the fact that those provisions speak in terms of a recipient's policy or practice, rather than individual instances, of disclosure. ${ }^{154}$ This "policy or practice" language suggests an aggregate, rather than individual, focus. ${ }^{155}$ Statutory provisions with an aggregate focus cannot give rise to individual rights. ${ }^{156}$

Congress also chose to expressly provide a mechanism for enforcing FERPA's nondisclosure provisions, which further supported the Court's conclusion that the nondisclosure provisions confer no right enforceable by a $\S 1983$ action. ${ }^{157}$ In FERPA, Congress expressly provided a relatively complex mechanism for federal review. ${ }^{158}$ According to the Court, express provision of this relatively complex enforcement mechanism counseled against a finding that Congress intended to create an "individually enforceable private right[]."159 Furthermore, FERPA was amended, four months after being enacted, to provide for a centralized review process and avoid conflicting, regional enforcements of the nondisclosure provisions. ${ }^{160}$ The Court reasoned that if Congress intended FERPA to be uniformly enforced, and provided a centralized review process to ensure that it is, then it is unlikely Congress intended to create a right that individuals could enforce by $\S 1983$ actions in state and federal courts nationwide, as that would surely lead to the nonuniform enforcement the amendment sought to avoid. ${ }^{161}$

e. Wright v. City of Roanoke Redevelopment \& Housing Authority May Stand for the Proposition That Agency Regulations Create or Define Statutory Rights

It has been argued that whether $\S 602$ disparate impact regulations are enforceable by $\S 1983$ turns on an interpretation of Wright v. City of Roanoke Redevelopment \& Housing Authority. ${ }^{162}$ If Wright is interpreted to stand for the proposition that agency regulations can create or define

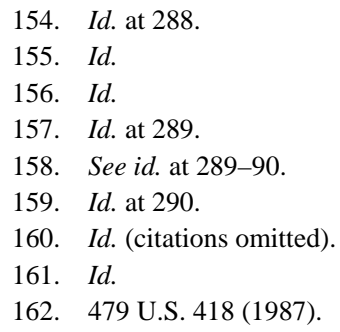


rights, a $\S 1983$ action may be used to enforce those rights. ${ }^{163}$ In Wright, tenants claimed that Roanoke violated their federal statutory right to pay only a certain percentage of their income in rent. ${ }^{164}$ Roanoke had done so by not including utility costs in its rent calculation, which tenants then had to pay in addition to rent. ${ }^{165}$ Agency regulations, not the federal statute itself, defined rent to include a reasonable amount for utilities. ${ }^{166}$ The Wright Court ultimately concluded that the regulations at issue created federal rights enforceable by $\S 1983 .{ }^{167}$ Although Wright was decided before Blessing, the Court appears to have applied the factors later enunciated in Blessing to determine that the regulations created a right enforceable by $\S 1983 .{ }^{168}$

To the extent Wright relies on the Blessing factors, it is unlikely to provide a basis for finding $\S 602$ disparate impact regulations create rights enforceable by $\S 1983$. Gonzaga requires unambiguous congressional intent to create such a right and renders the Blessing factors relevant only insofar as they demonstrate such intent. ${ }^{169}$

The Wright Court, however, did not rely solely on the Blessing factors, assigning weight to (1) the regulation at issue as a valid interpretation of the statute and (2) congressional failure to disagree with or amend the regulation while amending other parts of the statute. ${ }^{170}$ Under Wright, then, congressional failure to amend Title VI to prohibit disparate impact regulations while amending other parts of the statute may suggest that Congress has accepted such regulations as valid interpretations of the statute. ${ }^{171}$ If the disparate impact regulations are valid interpretations of Title VI, § 1983 may be used to enforce them. ${ }^{172}$

163. See Spital, supra note 20, at 115 (describing a dispute in interpretations of Wright, one of which asserts that regulations may create $\S 1983$ rights).

164. Wright, 497 U.S. at 420-22.

165. Id. at 421 .

166. Id. at 420 .

167. Id. at 431 .

168. See id. at 430-32 (stating that the regulation contained a mandatory limitation, was undeniably intended to benefit the class of which plaintiff was a part, and was not beyond the competency of the judiciary to enforce).

169. See supra notes $130-32$ and accompanying text. Spital asserts that regulations may create rights so long as they satisfy the Blessing factors. Spital, supra note 20, at 118 . This assertion, however, fails to account for Gonzaga's move away from the three Blessing factors to the focus on unambiguous congressional intent.

170. Wright, 479 U.S. at 430.

171. Spital, supra note 20, at 118.

172. See id. (noting that Gonzaga specifically referred to Title VI as a statute that clearly created rights; thus, a valid interpretation of that statute would create or define that right and be enforceable by $\S 1983)$. 


\section{Use of \& 1983 to Enforce Regulations Authorized by Statute: A Circuit Split}

As previously noted, ${ }^{173}$ although the Supreme Court in Sandoval held that federal regulations promulgated pursuant to $\S 602$ of Title VI prohibiting disparate impact discrimination could not be enforced by an implied private cause of action, it appeared to leave open the possibility they could be enforced by a $\S 1983$ action. ${ }^{174}$ Indeed, this possibility has created a split in the circuit courts of appeal.

1. The Majority Position: $\S 1983$ May Not Be Used to Enforce Regulations Authorized by Statute

A majority of the circuits to address the issue have held that disparate impact regulations promulgated under $\S 602$-or other regulations that are authorized by a given statute-do not create individual rights and therefore are not enforceable by a $\S 1983$ action.

\section{a. Save Our Valley v. Sound Transit}

In Save Our Valley v. Sound Transit, ${ }^{175}$ the Central Puget Sound Regional Transit Authority (Sound Transit) was in charge of building a light rail line connecting an area in north Seattle with an airport in SeaTac, Washington. ${ }^{176}$ The portion of the light rail line that was to pass through Seattle's Rainier Valley, a neighborhood populated predominantly by minorities, was to be built at street level, whereas other portions of the light rail line that were to pass through neighborhoods were to be elevated above street level or built underground. ${ }^{177}$ Save Our Valley brought suit under $\S 1983$, arguing that the plan to build the light rail line would have a disproportionately adverse (disparate) impact upon minorities. ${ }^{178}$ Save Our Valley claimed that this was a violation of the Department of Transportation's $\S 602$ regulation prohibiting disparate impact discrimination. ${ }^{179}$ Save Our Valley argued that the $\S 602$ regulation creates an individual federal right that is enforceable by a

\footnotetext{
173. See supra Part II.B.1.b.

174. See Alexander v. Sandoval, 532 U.S. 275, 293 (2001).

175. 335 F.3d 932 (9th Cir. 2003).

176. Id. at 934 .

177. Id.

178. Id

179. Id. at 934-35.
} 
$\S 1983$ action. $^{180}$ The district court rejected this argument and granted summary judgment to Sound Transit. ${ }^{181}$

On appeal, the issue for the Ninth Circuit was whether the Department of Transportation's § 602 disparate impact regulation created an individual federal right enforceable by a $\S 1983$ action. ${ }^{182}$ Resolution of this issue turned on the answer to a broader question: "Can a federal agency's regulations ever create individual rights enforceable through $\S$ 1983?"183 The decision in Save Our Valley began by recognizing that the circuits were split in answering this question. ${ }^{184}$

The Ninth Circuit noted that, on one side of the split, the "Third, Fourth, and Eleventh Circuits have held that an agency regulation cannot create an individual federal right enforceable through § 1983."185 According to the Ninth Circuit, each circuit on this side of the split had employed essentially the same reasoning. ${ }^{186}$ Each circuit had looked to the Supreme Court's $\S 1983$ cases for direction and found that the Court's key consideration in those cases was congressional intent-or lack thereof-to create the right that the plaintiff sought to enforce through $\S 1983 .{ }^{187}$ These circuits understood the Court, in its $\S 1983$ cases, to treat administrative regulations as "mere 'administrative interpretations of the statute." "188 As a result, these circuits interpreted the Court's § 1983 cases to establish "the principle that Congress creates rights by statute, and that valid regulations merely 'define' or 'flesh out' the contents of those rights."189 Thus, according to these circuits, regulations cannot create individual federal rights independent of those created by the statute authorizing the regulations. ${ }^{190}$

Each of the circuits that held federal regulations cannot create individual federal rights enforceable through $\S 1983$, prior to the Ninth Circuit's decision in Save Our Valley, did so prior to the Supreme Court's decisions in Sandoval and Gonzaga. ${ }^{191}$ The Ninth Circuit found

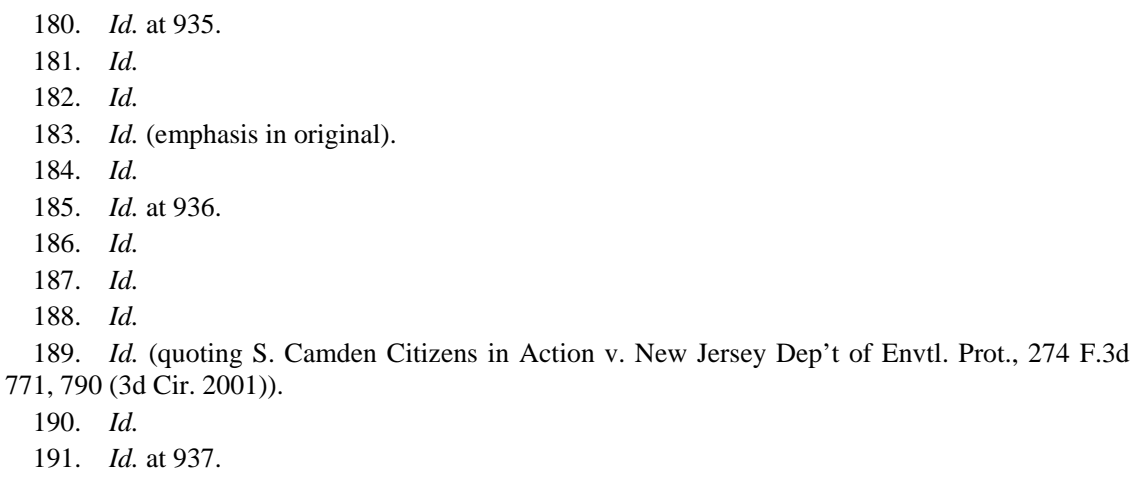


that these Supreme Court decisions strengthened the legal foundation underlying the decisions on this side of the circuit split. ${ }^{192}$ Both Sandoval and Gonzaga, according to the Ninth Circuit's interpretation, added support to the proposition that only Congress, by statute, can create individual federal rights-which means federal agencies, by promulgating regulations, cannot. $^{193}$ The Ninth Circuit therefore concluded that federal agency regulations cannot create individual rights enforceable by a $\S 1983$ action. ${ }^{194}$ As a result, Save Our Valley could not bring a $\S 1983$ action to enforce the Department of Transportation's $\S 602$ disparate impact regulations. ${ }^{195}$

b. The Sixth Circuit: A Switch from the Minority Position to the Majority Position

The Ninth Circuit, in Save Our Valley, noted that the Sixth Circuit took the minority position that agency regulations can create individual rights enforceable through a $\S 1983$ action. ${ }^{196}$ In Loschiavo v. City of Dearborn, the Sixth Circuit took this same position. ${ }^{197}$ However, the Sixth Circuit, in Caswell v. City of Detroit Housing Commission, reversed its position, relying on the Supreme Court's decisions in Sandoval and Gonzaga to hold that federal regulations cannot create individual federal rights enforceable by a $\S 1983$ action. ${ }^{198}$ In Johnson $v$. City of Detroit, the Sixth Circuit affirmed that it had reversed course and adhered to the position that agency regulations cannot create individual federal rights enforceable by a $\S 1983$ action. ${ }^{199}$

2. The Minority Position: $\S 1983$ May Be Used to Enforce Agency Regulations Authorized by Statute

Although a majority of circuits to address the issue have held that federal regulations authorized by federal statute cannot be enforced by a

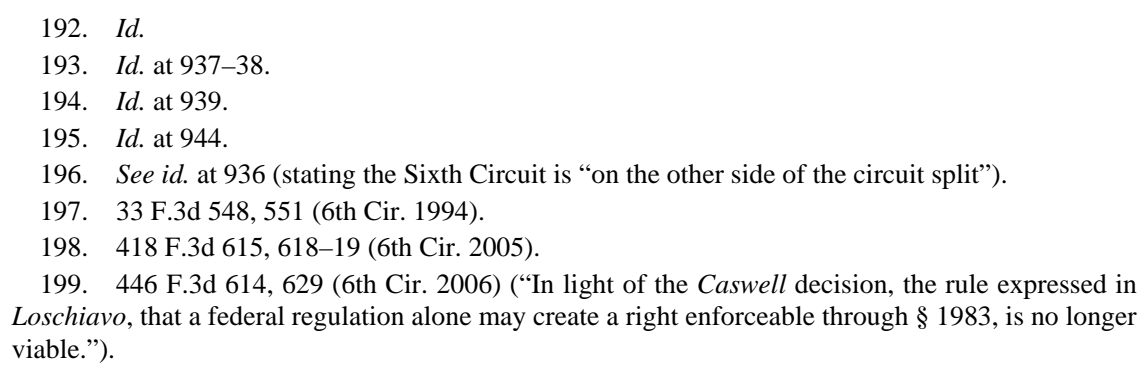

199. 446 F.3d 614, 629 (6th Cir. 2006) ("In light of the Caswell decision, the rule expressed in Loschiavo, that a federal regulation alone may create a right enforceable through § 1983, is no longer viable.”). 
$\S 1983$ action, two circuits have found that such regulations can be enforced by a $\S 1983$ action.

a. Samuels v. District of Columbia and the D.C. Circuit: Agency

Regulations May Create or Define Federal Rights; Thus, § 1983

Should Be Available to Enforce § 602 Disparate Impact Regulations

The D.C. Circuit, in Samuels v. District of Columbia, was the first circuit to hold that federal regulations could create individual federal rights enforceable by an action under $\S 1983 .{ }^{200}$ In Samuels, the plaintiffs alleged that District of Columbia public housing officials had violated Department of Housing and Urban Development (HUD) regulations. ${ }^{201}$

The D.C. Circuit found that the HUD regulations at issue had the "full force and effect of federal law" because "they are issued under a congressional directive to implement specific statutory norms and they affect individual rights and obligations."202 The D.C. Circuit also found that, under the Supreme Court's precedent, the "laws" clause of $\S 1983$ is broad enough to support a $\S 1983$ action to enforce "federal regulations adopted pursuant to a clear congressional mandate that have the full force and effect of law.”203 The D.C. Circuit pointed to Supreme Court precedent holding that such regulations-those adopted pursuant to a clear congressional mandate-have been recognized as part of the body of federal law. ${ }^{204}$ The D.C. Circuit then cited Thiboutot ${ }^{205}$ for the proposition that $\S 1983$ provides a remedy for a violation of any federal law, not just some subsets of federal laws. ${ }^{206}$

It is noteworthy that the D.C. Circuit decided Samuels in 1985 so it could only base its decision on cases decided before 1985. Obviously, the Supreme Court as well as lower courts have decided cases involving both Title VI and § 1983 since 1985. Some of these post-1985 cases may cast doubt on the validity of the D.C. Circuit's decision in Samuels, but not necessarily, and Samuels has not been overruled. Furthermore, the D.C. Circuit is not the only circuit to find that federal regulations

\footnotetext{
200. 770 F.2d 184, 199 (D.C. Cir. 1985).

201. Id.

202. Id.

203. Id.

204. Id

205. 448 U.S. 1; see supra Part II.B.2.a.

206. Samuels, 770 F.2d at 199.
} 
may create individual federal rights enforceable through $\S 1983$, and another circuit has so found as recently as 2002.

b. Robinson v. Kansas and the Tenth Circuit: $\S 1983$ Is Available to

Enforce $\S 602$ Disparate Impact Regulations

In 2002, in the case of Robinson v. Kansas, the Tenth Circuit found that a $\S 1983$ action, brought against state officials and seeking prospective injunctive relief, may be used to enforce $\S 602$ disparate impact regulations. ${ }^{207}$ In Robinson, the plaintiffs challenged Kansas's school-financing scheme, claiming that the scheme and its enforcement had a discriminatory disparate impact on minority students and students who are not of United States origin. ${ }^{208}$ The plaintiffs argued that this was a violation of $\S 602$ disparate impact regulations and sought to enforce those regulations through a $\S 1983$ action. $^{209}$

The Tenth Circuit first noted that the Supreme Court's decision in Sandoval prohibited a private cause of action under Title VI to enforce the $\S 602$ disparate impact regulations. ${ }^{210}$ The Tenth Circuit then plainly stated that the $\S 602$ disparate impact regulations are enforceable by a $\S 1983$ action brought against state officials and seeking prospective injunctive relief. ${ }^{211}$ The Tenth Circuit, however, offered no explanation for why it found that the $\S 602$ disparate impact regulations are enforceable by a $\S 1983$ action. ${ }^{212}$

\section{ANALYSIS}

Courts, and ultimately the Supreme Court, should allow the use of a $\S 1983$ action to enforce $\S 602$ regulations prohibiting disparate impact discrimination. There are three primary reasons for this. First, the use of $\S 1983$ actions to enforce $\S 602$ disparate impact regulations replaces an overly formalistic approach to Title VI with a much more functionalist approach. This functionalist approach is much better able to meet the overall goals and purpose of Title VI.

\footnotetext{
207. 295 F.3d 1183, 1187 (10th Cir. 2002).

208. Id. at 1186.

209. Id. at 1187.

210. Id. at $1186-87$.

211. Id. at 1187.

212. See Spital, supra note 20, at 112 ("[T]he Tenth Circuit's holding on this point was not supported by a reasoned analysis” other than citing a comment from Justice Stevens’s dissent).
} 
Second, as a legal matter, use of $\S 1983$ actions to enforce $\S 602$ disparate impact regulations fits within the Supreme Court's precedents. Section 1983 may only be used to enforce federal rights secured by the Constitution and federal laws. It is plausible, given the text and structure of Title VI, that disparate impact regulations promulgated under § 602 establish or define individual federal rights enforceable by a $\S 1983$ action.

Finally, use of the $\S 1983$ action to enforce $\S 602$ disparate impact regulations is warranted because the need for a mechanism to enforce those regulations arises in the first instance only because of an untenable distinction between "intentional" and "disparate impact" discrimination. Because it may be impossible to distinguish between intentional and disparate impact discrimination, it makes little sense to prevent only intentional discrimination.

\section{A. A More Functionalist Approach Is Preferred to the Current, Overly Formalistic Approach Because it Better Achieves the Overall Goals and Purpose of Title VI}

As outlined in Part II, the Supreme Court has set up a complex framework of legal rules governing Title VI. Under this framework, Title VI does not provide a private cause of action to enforce $\S 602$ regulations prohibiting disparate impact discrimination. ${ }^{213}$ Even if this proposition is accepted as settled law, a $\S 1983$ action should be allowed to enforce $\S 602$ disparate impact regulations. Allowing a $\S 1983$ action to enforce such regulations represents a far more functionalist approach to the issue than the current, overly formalistic approach taken by the Supreme Court in the context of implied private causes of action. The more functionalist approach better achieves the overall goals and purpose of Title VI.

Before addressing any of the legal rules surrounding Title VI, it is helpful to understand the overall goals and purpose of Title VI. Such an understanding is helpful because legal rules governing Title VI should be formulated to further its overall goals and purpose, not run contrary to them. The legislative history of Title VI clearly demonstrates its overall goals and purpose.

According to Senator John Pastore, "[Title VI] has a simple purpose - to eliminate discrimination in federally financed programs.",214

213. See supra note 47 and accompanying text.

214. 110 CONG. REC. 7054 (1964) (statement of Sen. Pastore). 
It is noteworthy that that there are no qualifications to the type of discrimination Congress sought to eliminate. President John F. Kennedy, in encouraging Congress to pass what would eventually become Title VI, stated the following:

Simple justice requires that public funds, to which all taxpayers of all races contribute, not be spent in any fashion which encourages, entrenches, subsidizes, or results in racial discrimination. Direct discrimination by Federal, State, or local governments is prohibited by the Constitution. But indirect discrimination, through the use of Federal funds, is just as invidious; and it should not be necessary to resort to the courts to prevent each individual violation. ${ }^{215}$

These statements make clear that the purpose of Title VI was, and is, to eliminate racial discrimination in federally financed programs. Neither statement contains an adjective-like "intentional"-modifying the type of discrimination Title VI was intended to eliminate. In fact, President Kennedy's statement demonstrates a clear intention to prohibit distribution of federal funds that results in racial discrimination-and spending that simply results in racial discrimination is precisely the disparate impact discrimination prohibited by $\S 602$ disparate impact regulations.

Given the evidence in Senator Pastore's statement that Title VI was intended to eliminate all types of racial discrimination-not just intentional discrimination - and the evidence in President Kennedy's statement that Title VI was intended to eliminate even disparate impact discrimination, it is clear that Title VI was intended to be interpreted broadly. In other words, Title VI was to be interpreted so as to reach, and eliminate, all forms of racial discrimination, including disparate impact discrimination, in programs receiving federal funding. Thus, legal rules adopted to govern Title VI should further this purpose.

Because the Supreme Court in Sandoval foreclosed the possibility of an implied private cause of action in Title VI to enforce $\S 602$ disparate impact regulations, ${ }^{216}$ a $\S 1983$ action should be allowed to enforce them. If neither an implied private cause of action nor a $\S 1983$ action is available to enforce $\S 602$ disparate impact regulations, there is no mechanism by which individuals may enforce the very regulations that are intended to protect them. Federally funded entities would be able to racially discriminate by distributing funds in a manner that simply

215. H.R. Doc. No. 88-124, pt. 3, at 12 (1963) (emphasis added).

216. See supra Part II.B.1.b. 
resulted in discrimination on the basis of race, so long as the funds were not expressly distributed on the basis of race in the first instance. The Sandoval Court, in its overly formalistic approach, failed to consider or appreciate this possibility and did nothing to further Title VI's overall purpose of eliminating all forms of racial discrimination in federally funded programs. Thus, a $\S 1983$ action should be allowed to enforce $\S 602$ disparate impact regulations and thereby better serve Title VI's overall goals and purpose.

B. Because Disparate Impact Regulations Promulgated Pursuant to $\S 602$ Are Intended to Effectuate the Antidiscrimination Provision of $\S$ 601, Those Regulations Create Individual Federal Rights and Should Be Enforceable through \& 1983

As a legal matter, the key inquiry in determining whether $\S 602$ disparate impact regulations may be enforced by a $\S 1983$ action involves a two-step analysis. First, one must consider whether $\S 602$ disparate impact regulations create or define a federal right. As noted above, this requires, pursuant to Gonzaga $v$. Doe, unambiguous congressional intent to confer an individual federal right. ${ }^{217}$ Second, one must consider whether the right is one for which $\S 1983$ was intended to provide a remedy or enforcement mechanism. ${ }^{218}$ As previously noted, however, if a federal right exists, $\S 1983$ is presumed to be available as a remedy or enforcement mechanism. ${ }^{219}$

Beginning with the text of Title VI, the statute itself draws no distinction between intentional and disparate impact discrimination. The statute prohibits only "discrimination" without any adjective. ${ }^{220}$ The Supreme Court noted in Gonzaga that Title VI has been found to confer an individual right-the right to be free from the prohibited discrimination-because the text of the statute is focused on the protected class. ${ }^{221}$ Thus, the Supreme Court, in a case that established a more stringent standard for determining whether a statute confers individual rights, cited Title VI, specifically, as an example of a statute that confers individual rights. ${ }^{222}$ This, coupled with the fact that the text of Title VI does not limit the discrimination prohibition to intentional

\footnotetext{
217. See supra Part II.B.2.d.

218. See supra Part II.B.2.c.

219. See supra Part II.B.2.c.

220. See supra Part II.A.1.

221. Gonzaga Univ. v. Doe, 536 U.S. 273, 284 (2002).

222. See id.
} 
discrimination, clearly evinces a congressional intent to create a right to be free from all types of discrimination. Because this right includes the rights to be free from disparate impact discrimination, a $\S 1983$ action should be available to enforce $\S 602$ disparate impact regulations that create or define that right.

In foreclosing the availability of an implied private cause of action to enforce § 602 disparate impact regulations, the Sandoval Court accorded significant, if not dispositive, weight to the fact that the language of $\S 602$ focuses on the regulating federal agencies, as opposed to $\S 601$ 's focus on the class of persons protected by Title VI. ${ }^{223}$ According to the Court's reasoning, statutory provisions focusing on the regulating agencies, rather than the protected class, evince no congressional intent to create rights. $^{224}$ Although this may be true under the Court's precedent, the Sandoval Court ignored § 602's reference to § 601 in making this assertion.

Section 602 explicitly authorizes federal agencies to promulgate regulations that "effectuate the provisions of [ $\left.\begin{array}{l}\S 601\end{array}\right]$," 225 thereby importing $\S 601$ 's focus on the protected class into $\S 602$. Because the $\S 602$ regulations are to effectuate the provisions of $\S 601$, Congress clearly intended such regulations to be promulgated for the benefit of the protected class. It is difficult to see, then, how $\S 602$ lacks the "rightscreating" language-language focused on the benefitted class-that evinces congressional intent to create rights. If $\S 601$ evinces congressional intent to, and does in fact, create individual rights, then $\S 602$ must also evince congressional intent to either (1) create rights or (2) define rights - by promulgation of agency regulations effectuating $\S 601$ - created by $\S 601$. Because the Gonzaga Court recognized that $\S 601$ creates individual rights, ${ }^{226}$ it follows logically that $\S 602$ either (1) creates rights or (2) defines the rights created by $\S 601$.

Title VI, furthermore, not only authorizes federal agencies to promulgate regulations under $\S 602$, but directs federal agencies to do so. ${ }^{227}$ Had Congress merely authorized, rather than directed, federal agencies to promulgate regulations effectuating the provisions of $\S 601$, one could reasonably argue that the regulations do not create or define

223. See Alexander v. Sandoval, 532 U.S. 275, 288-89 (2001) (emphasizing that the language of $\S 602$ does not create rights and focuses on the regulating agency).

224. Id.

225. 42 U.S.C. § 2000d-1 (2006) (emphasis added).

226. Gonzaga, 536 U.S. at 284 n.3 (recognizing $§$ 601's creation of individual rights by its focus on the benefitting class of people).

227. 42 U.S.C. § 2000d-1. 
any rights whatsoever. If Congress intended the regulations to create or define rights protected by Title VI, it is unlikely that the regulations would be optional. Thus, the fact that Congress actually directed federal agencies to promulgate regulations effectuating the antidiscrimination provision of $\S 601$ evinces congressional intent to create or definethrough the promulgation of agency regulations - the scope of rights encompassed in § 601 .

Congress, in $\S 601$, sought generally to eliminate discrimination in federally funded programs and thereby created a right to be free from the prohibited discrimination. In $\S 602$, Congress directed federal agencies to promulgate regulations giving substance to this general goal. Thus, if $\S 602$ regulations prohibiting disparate impact discrimination were necessary to effectuate the antidiscriminatory provision of $\S 601$, such regulations would create, or define, rights encompassed in and protected by $\S 601$. These rights, as created or defined by $\S 602$ regulations, should be enforceable by a $\S 1983$ action.

\section{Because the Current Distinction Between "Intentional" and "Disparate Impact" Discrimination Is Untenable, § 1983 Should Be Available to Enforce \& 602 Disparate Impact Regulations so That All Forms of Discrimination May Be Eliminated}

The need for a $\S 1983$ action to enforce $\S 602$ regulations prohibiting disparate impact discrimination arises only because of the distinction between intentional and disparate impact discrimination. If, in accord with the intent of Congress, the Supreme Court had broadly interpreted Title VI to reach and eliminate all forms of discrimination, then an implied private cause of action would be available to enforce the right to be free from both intentional and disparate impact discrimination. ${ }^{228}$ The Supreme Court, however, has not interpreted Title VI in the broad manner its drafters intended.

As outlined above, the Supreme Court has held that $\S 601$ of Title VI reaches only intentional discrimination. ${ }^{229}$ Disparate impact discrimination is reached only by $\S 602$ regulations. ${ }^{230}$ Because the implied private cause of action contained in Title VI may only be used to enforce $\S 601$ 's ban on intentional discrimination, ${ }^{231}$ an alternative

\footnotetext{
228. See supra Part II.B.1.b.

229. See supra notes $46-47$ and accompanying text.

230. See supra notes 58-62 and accompanying text.

231. See supra notes $76-77$ and accompanying text.
} 
mechanism, such as $\S 1983$, is needed to enforce $\S 602$ disparate impact regulations. However, the distinction between intentional and disparate impact discrimination is untenable, and use of $\S 1983$ to enforce $\S 602$ disparate impact regulations is therefore warranted to ensure that both forms of discrimination are effectively prohibited.

Intentional discrimination is understood to encompass any policy that expressly guides distribution of federal funds on the basis of race. ${ }^{232}$ Disparate impact discrimination is understood to encompass policies that do not expressly guide distribution of federal funds on the basis of race but, nonetheless, result in a disproportionally adverse, or disparate, impact upon certain racial groups. ${ }^{233}$ The first hypothetical policy in Part I-expressly distributing funds on the basis of race-is an example of so-called intentional discrimination. The second hypothetical policy in Part I-distributing funds based on the size of student organizations, but resulting in no funding to groups composed primarily of racial minorities-is an example of so-called disparate impact discrimination. Although the distinction between intentional and disparate impact discrimination may make sense as a logical matter, it is untenable as a practical matter. This is so because "intentional" speaks to a state of mind, but a state of mind may easily be disguised, leaving disparate impact as the only evidence of intentional discrimination.

An entity receiving federal funds may intentionally discriminate on the basis of race and yet do so without engaging in so-called intentional discrimination. Such an entity need only find a proxy for race and distribute funds based on that proxy. ${ }^{234}$ The result would be that funds are distributed in a manner that results in racial discrimination-which is the definition of disparate impact discrimination. Disparate impact discrimination therefore can be intentional, which renders untenable, as a practical matter, the distinction between intentional and disparate impact discrimination. Even if one accepts the proposition that Title VI contains an implied private cause of action that reaches only intentional discrimination, it is undeniable that in at least some instances the only

232. See supra note 4 and accompanying text.

233. See supra note 5 and accompanying text; see also supra Part II.A.1.

234. See, e.g., McBride v. Lawstal, Inc., No. 1:96-cv-0196-cc, 1996 WL 755779, at *1-2 (N.D. Ga. Sept. 19, 1996) (finding an employment policy that declined candidates with "braided hairstyles" was not discriminatory, in part, towards African Americans because no race was specifically targeted by the policy, as all races are capable of having braided hairstyles (citing Rogers v. Am. Airlines, 527 F. Supp. 229, 231-33 (S.D.N.Y. 1981))); Camille Gear Rich, Performing Racial and Ethnic Identity: Discrimination by Proxy and the Future of Title VII, N.Y.U. L. REV. 1134, 1140-42 (2004) (giving as an example of discrimination denying a job position to an otherwise qualified candidate claiming his accent was unsuitable instead of citing race outright). 
evidence of intentional discrimination is evidence of disparate impact on particular racial groups. ${ }^{235}$ If, however, a prohibition on discrimination that merely results in racial discrimination is not enforceable by a private cause of action, then at least some instances of intentional discrimination cannot, and will not, be eliminated. Thus, there needs to be a private cause of action to enforce $\S 602$ regulations prohibiting disparate impact regulations. Because the Sandoval Court has foreclosed the possibility of an implied private cause of action in Title VI to enforce $\S 602$ disparate impact regulations, ${ }^{236}$ a $\S 1983$ action should be allowed to enforce such regulations.

\section{CONCLUSION}

Legal rules, no matter how black and white they may appear, do not operate in a vacuum and may be subject to manipulation in the realworld context in which they operate. Such is the case with Title VI and the legal rules that flow from it. The Supreme Court has made clear that $\S 601$ of Title VI reaches only intentional discrimination. As a result, the implied private cause of action contained in Title VI may only be used to enforce § 601's prohibition on intentional discrimination.

The private cause of action that exists in Title VI cannot be used to enforce $\S 602$ regulations prohibiting disparate impact discrimination. This leaves entities receiving federal funding free to engage in racial discrimination, so long as they are able to find a race-neutral proxy allowing them to do so. Because the purpose of Title VI is to protect individuals from discrimination based on race, color, or national origin, the law should not be overly formalistic and ignore real-world actors who are technically complying with the requirements of Title VI-by not intentionally discriminating based on race-but are undermining its very purpose-by adopting facially race-neutral policies that have a disparate impact on particular minority groups.

The $\S 1983$ action is a viable alternative mechanism to enforce $\S 602$ disparate impact regulations. The $\S 1983$ action is intended as an enforcement mechanism for rights secured by federal statute. Title VI, a federal statute, confers upon individuals the right to be free from all types of discrimination. This includes intentional forms of

235. See, e.g., Grant v. Bethlehem Steel Corp., 635 F.2d 1007, 1014 (2d Cir. 1980) (stating that sometimes discrimination can be inferred from disparate impact).

236. See Alexander v. Sandoval, 532 U.S. 275, 288-89, 291 (2001) (finding that Congress did not intend to create a private cause of action and that absent congressional authorization, a regulation cannot create one). 
discrimination, which are covered by $\S 601$, as well as forms of discrimination that may appear to be unintentional on their face but have the same discriminatory effect, which are covered by § 602 disparate impact regulations. As both are individual rights secured by Title VI, a federal statute, the $\S 1983$ action should be available to enforce both of them. 